\title{
Quantifying Biogenic Versus Detrital Carbonates on Marine Shelf: An Isotopic Approach
}

\author{
V. Pasquier ${ }^{1,2 *}$, S. Revillon ${ }^{2,3}$, E. Leroux ${ }^{4}$, S. Molliex ${ }^{2,5}$, L. Mocochain ${ }^{6}$ and M. Rabineau ${ }^{2}$ \\ ${ }^{1}$ Department of Earth and Planetary Sciences, Weizmann Institute of Science, Rehovot, Israël, ${ }^{2}$ Laboratoire Geosciences \\ Océan LGO, UMR 6538 (CNRS/Univ Brest/Univ Bretagne Sud), IUEM, Plouzané, France, ${ }^{3}$ SEDISOR, IUEM, Plouzané, \\ France, ${ }^{4}$ IFREMER, Laboratoire Géodynamique et enregistrement Sédimentaire, Plouzané, France, ${ }^{5}$ CRPG, UMR 7358 , \\ CNRS-Université de Lorraine, Vandœuvre-lès-Nancy, France, ${ }^{6}$ Sorbonne Université, Institut des Sciences de la Terre de \\ Paris (ISTeP), Paris, France
}

The terrigenous sedimentary budget of passive margins, records variations in past sedimentary fluxes, and thus can be used to infer past variations of Earth surface deformation processes or climate change. Accurate estimates of sediment fluxes over various times and spatial scales are therefore crucial. Traditionally, offshore sediment volume determination only considers siliciclastic accumulation, the carbonate fraction (i.e., $\mathrm{CaCO}_{3}$ ) being considered only as in situ production. Here we propose a new geochemical methodology to decipher and quantify the number of detrital

OPEN ACCESS

Edited by: Brian W. Romans, Virginia Tech, United States

Reviewed by: Lars Reuning, University of Kiel, Germany Mike Rogerson, University of Hull, United Kingdom

*Correspondence: V. Pasquier virgil.pasquier@weizmann.ac.il

Specialty section: This article was submitted to Sedimentology, Stratigraphy and Diagenesis,

a section of the journal

Frontiers in Earth Science

Received: 06 March 2019

Accepted: 07 June 2019

Published: 03 July 2019

Citation:

Pasquier V, Revillon S, Leroux E,

Molliex S, Mocochain L and Rabineau M (2019) Quantifying Biogenic Versus Detrital Carbonates

on Marine Shelf: An Isotopic Approach. Front. Earth Sci. 7:164. doi: 10.3389/feart.2019.00164 carbonates in comparison to in situ produced biogenic carbonates. This isotopic approach enables considering the export of detrital carbonates and investigating its effect on sediment budgets. This study, located in the Gulf of Lion, is based on a $300 \mathrm{~m}$ long sediment borehole located near the shelf break and covering the last 500000 years (i.e., five glacial-interglacial periods). Strontium isotope $\left({ }^{87} \mathrm{Sr} /{ }^{86} \mathrm{Sr}\right.$ ) of carbonate fractions (0.70809 to 0.70858) are significantly less radiogenic than modern seawater (i.e., 0.7092) and show fluctuations in agreement with stratigraphic and climatic variations. These results suggest an unsuspected high export of detrital carbonates from the catchment area during both glacial (between 55 and 85\% of the sedimentary carbonate fraction) and interglacial (between 30 and 50\%) conditions. Thus, not only do detrital carbonate fluxes need to be factored into sediment flux calculations, but these results also suggest that detrital carbonate components could potentially have a strong influence on bulk carbonate ${ }^{87} \mathrm{Sr} /{ }^{86} \mathrm{Sr}$ ratios when not obtained from micro drilled biogenic carbonates, such as the entirety of the Precambrian $\mathrm{Sr}$ chemostratigraphic record.

\section{Keywords: ${ }^{87} \mathrm{Sr} /{ }^{86} \mathrm{Sr}_{\text {carbonate }}$, detrital carbonate export, source-to-sink, glacial - interglacial, strontium isotope stratigraphy}

\section{INTRODUCTION}

An extensive dataset has been collected over the last decade on marine carbonates and fossils, to document past variations in the strontium isotopic composition record $\left({ }^{87} \mathrm{Sr} /{ }^{86} \mathrm{Sr}\right)$, as a tool to reconstruct changes in the seawater composition through Earth's history. These past variations are of interest for two reasons: first, ${ }^{87} \mathrm{Sr} /{ }^{86} \mathrm{Sr}$ ratios measured on marine carbonate offer a widely 
used chronostratigraphic tool (SIS - Strontium Isotope Stratigraphy; for reviews of SIS the readers should referred to Elderfield, 1986; McArthur, 1994; Veizer et al., 1997, 1999; McArthur et al., 2012); second, secular changes in Sr isotope composition provide information about the geochemical cycling of strontium in the ocean, weathering processes, hydrothermal circulation, and carbonate dissolution at the sea-floor (Burke et al., 1982; De Paolo and Ingram, 1984; Veizer, 1989; Prokoph et al., 2008; Allègre et al., 2010 among others).

Since the rapid increase of calcifying organisms (i.e., Mesozoic), the SIS method relies on two assumptions: (i) strontium isotopes composition measurements from well preserved, non-altered, shell material (i.e., bivalves, rudist, belemnites, planktonic foraminifera) are assumed to reflect the seawater $\mathrm{Sr}$ isotope composition from which they precipitated (Veizer, 1989; McArthur et al., 2012); (ii) the world's ocean is homogenous with respect to ${ }^{87} \mathrm{Sr} /{ }^{86} \mathrm{Sr}$, and always has been. Such uniformity is expected because $\mathrm{Sr}$ residence time in the ocean (4 Myr; Broeker, 1963; Goldberg, 1963; Hodell et al., 1990) is far longer than their mixing time ( $\sim 10^{3}$ years). Since the 1980 s, the SIS tool relies on the extensive compilation of data, cross calibration between carbonate producers (ammonites, foraminifera, calcareous nannofossils) and/or other geochemical proxies $\left(\delta^{13} \mathrm{C}, \delta^{18} \mathrm{O}\right)$. Extensive compilations of measured ${ }^{87} \mathrm{Sr} /{ }^{86} \mathrm{Sr}$ in marine material yield to the development of numerical age determination tools (McArthur et al., 2012 for a thorough review). The degree to which SIS numerical dating is correct mostly depends on the slope and the accuracy of the age model during the given time interval, as well as the quality and state of preservation of the studied material. Given the difficulty of dating sedimentary material, especially during the Paleozoic and Precambrian era, it could be tempting to use a "bulk" SIS approach by measuring the ${ }^{87} \mathrm{Sr} /{ }^{86} \mathrm{Sr}$ ratio of the entire carbonate fraction preserved in the sediment. However, such a carbonate component may not necessarily entirely be produced in situ and could include a significant detrital proportion. If so, not only would the SIS-derived ages be biased, but the inferred flux of detrital material to total sediment would also be underestimated. This is of great importance when calculating sedimentation rates in stratigraphic simulations studies (Allen, 1974; Castelltort and Van Den Driessche, 2003; Allen, 2008; Armitage et al., 2011, 2013; Simpson and Castelltort, 2012; Romans et al., 2016); but also when reconstructing temporal variations in the marine ${ }^{87} \mathrm{Sr} /{ }^{86} \mathrm{Sr}$ or to understand the relative $\mathrm{Sr}$ fluxes related to continental weathering versus hydrothermal inputs over time (e.g., Burke et al., 1982; Veizer, 1989; Veizer et al., 1999; Halverson et al., 2007; Prokoph et al., 2008).

In this study, we examined the $\mathrm{Sr}$ isotope compositions preserved in the sediment carbonate fractions from the Gulf of Lion which were deposited during one glacial advance and the following retreat between 160 to $120 \mathrm{ka}$, i.e., over the MIS 6 to MIS 5 transition. The goals of this exploratory project were first to test whether detrital carbonates could be preserved in shelf accumulation and developed an isotopic approach that could help in their quantification.
We secondly explore their potential effect on sedimentary fluxes calculations.

\section{GEOLOGICAL BACKGROUND AND ANALYTICAL RESULTS}

The Gulf of Lion (GoL), located in the North-Western Mediterranean, is characterized by a wide continental shelf $(70 \mathrm{~km})$ that was sub-aerially exposed during glacial periods over the Late Quaternary period (Rabineau et al., 2005). The sedimentation is mainly dominated by the Rhône River inputs which currently provide about $80 \%$ of the total sediment flux (Aloisi et al., 1977; de Madron et al., 2000; Molliex et al., 2016). Rivers from the Pyrenees and Languedoc (Herault, Orb, Aude, Agly, Tech and Têt; Figure 1) supply the remaining fraction. The GoL catchment is composed of (i) crystalline rocks, located in mountainous areas (Inner Alps, Massif Central, Pyrenees), and (ii) a large part of carbonated rocks, mostly marl and limestone from the Mesozoic era (Jurassic and Cretaceous) located in Alpine foreland. Some Cenozoic carbonates (Eocene and Miocene), mostly bioclastic and continental sandy limestone, are also present in the downstream part of the catchment and in the foreland of the Alps and Pyrenees and (iii) Pliocene-Quaternary formations which consist of fluvial deposits (Molliex et al., 2016). This study is based on sediment samples collected from borehole PRGL1-4 (Figure 1), drilled in the framework of the EU PROMESS project ${ }^{1}$, which sampled a $300 \mathrm{~m}$ long continuous record spanning the last five glacial-interglacial cycles. The sedimentary succession consists of five progradational units related to the 100-kyr glacio-eustatic cyclicity (Rabineau et al., 2005, 2006). In addition to the moving (regressiontransgression) of the shoreline and associated sedimentary environments, the sea-level strongly controls the connection of the riverine inputs with the upper slope setting. As a consequence, the sediment column at PRGL1-4 is essentially composed of fine siliciclastic grains detrital sediment with several interbedded $\mathrm{cm}$-thick sandy-size layers, made mostly of foraminifera shells accumulation, marking the periods of shelf maximum flooding during interglacial periods (Figure 1; Sierro et al., 2009; Frigola et al., 2012). The stacking of 100kyr sequences is favored by a high subsidence rate in that area (Rabineau et al., 2014). Sediment provenance studies indicate a predominance of Rhône river sediment (Revillon et al., 2011). These studies however, only considered siliciclastic material and, no reliable information on carbonate export is available, although carbonated rocks constitute more than $50 \%$ of the Gulf of Lion catchment area, and $40 \%$ of the eroded volumes (Molliex et al., 2016).

A total of 12 sediment samples from PRGL1-4 were selected along the glacial retreat from MIS 6 (i.e., $160 \mathrm{ka}$ ) toward the MIS 5 climatic optimum (i.e., $120 \mathrm{ka}$ ), together with 10 samples from modern Rhône river tributaries riverbeds (see Figure 1 for location). In the present study we analyzed the

${ }^{1}$ https://doi.pangaea.de/10.1594/PANGAEA.902768 

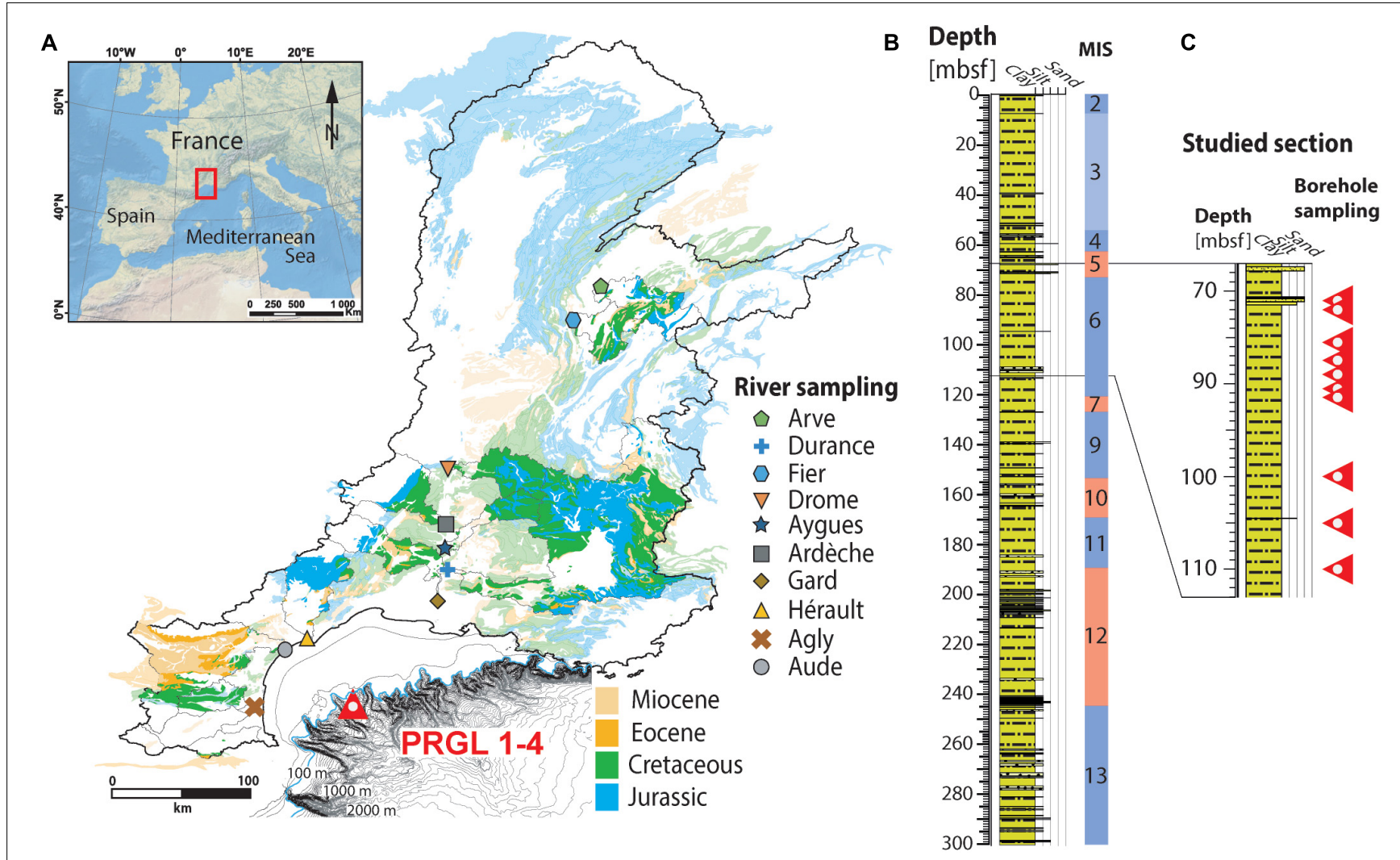

FIGURE 1 | (A) Map of the Gulf of Lion and its watershed with the location of the PRGL1-4 core (42.690N; 3.838E), and riverbed samples. Distribution of stratigraphic units containing carbonate rocks in the catchment are color-coded by age of deposition. (B) Composite lithological and sedimentological log of PRGL 1-4, and associated climatic context where pink and blue bands corresponds to interglacial and glacial periods (dark and light blue bands represent sensu-stricto and sensu-lato, respectively). MIS refers to Marine Isotopic Stage according to Railsback et al., 2015. (C) Close up view of the studied section with samples location.

Sr isotope compositions, trace elements, and $\mathrm{CaCO}_{3}$ contents of bulk carbonate samples extracted (i.e., leached) from both marine (i.e., PRGL1-4) and river sediments (i.e., from very coarse sand to clay; Supplementary Table S1), using 5\% acid acetic digestion. Strontium was isolated from the matrix by column chromatography using a Sr-Spec resin (Eichrom ${ }^{\circledR}$ ) prior to analysis by TIMS (Thermo Fisher Scientific TRITON) at the Pôle Spectrometrie Océan (Brest, France). Purified Sr were loaded on single $\mathrm{W}$ and measured on static mode. All measured $\mathrm{Sr}$ ratios were normalized to ${ }^{86} \mathrm{Sr} /{ }^{88} \mathrm{Sr}=0.1194$. During the course of analysis, $\mathrm{Sr}$ isotope compositions of standard solution NBS987 gave ${ }^{87} \mathrm{Sr} /{ }^{86} \mathrm{Sr}=0.710259 \pm 7(2 \sigma$, $n=9$, recommended value 0.710250 ). Total procedural blanks were $<200 \mathrm{pg}$ of $\mathrm{Sr}$ and therefore negligible in all cases (see Supplementary Material for a complete description of the methodology).

Throughout the studied interval, the Sr isotopic compositions of the carbonate fractions show significant variations from 0.70809 to 0.70858 , whereas carbonate contents vary from 29.5 to 42.5 wt.\%, (Figure 2). Within river samples, ${ }^{87} \mathrm{Sr} /{ }^{86} \mathrm{Sr}$ varies between 0.70741 and 0.70855 and the carbonate content ranges between 2.0 and 40.3 wt.\% (Supplementary Figure S1). No clear trend was observed, neither in marine nor in river sediments, between ${ }^{87} \mathrm{Sr} /{ }^{86} \mathrm{Sr}$ ratio and $\mathrm{CaCO}_{3}$ content $\left(\% \mathrm{CaCO}_{3}\right)$, nor with
[Sr], (Supplementary Figure S2). All data reported in this study are available within the Supplementary Files, and online at http: //www.pangaea.de/Projects/PROMESS1/.

\section{EVIDENCE FOR A DETRITAL CARBONATE INPUT}

Seawater ${ }^{87} \mathrm{Sr} /{ }^{86} \mathrm{Sr}$ variations are often used to infer changes in the global strontium geochemical cycles, long-term variations of carbonate rocks erosion, or variations in the marine strontium reservoir through time. Most recently, ${ }^{87} \mathrm{Sr} /{ }^{86} \mathrm{Sr}$ variations in carbonates have been also used to establish continuous highresolution seawater curves for the last 500 Myr (Howarth and McArthur, 1997; McArthur et al., 2001 among others). In this case-study, sediment was deposited offshore between 120 and $160 \mathrm{ka}$, a time-span shorter than the residence time of strontium in the ocean, i.e., 4 Myr (Broeker, 1963; Goldberg, 1963; Hodell et al., 1990) and during which the Mediterranean basin remained well connected to the open world ocean via the Strait of Gibraltar (Hernández-Molina et al., 2014; Rohling et al., 2014). Therefore, variations in the carbonate ${ }^{87} \mathrm{Sr} /{ }^{86} \mathrm{Sr}$ ratios analyzed here cannot reflect changes in seawater $\mathrm{Sr}$ isotope composition and the observed deviation between our ${ }^{87} \mathrm{Sr} /{ }^{86} \mathrm{Sr}$ results from 


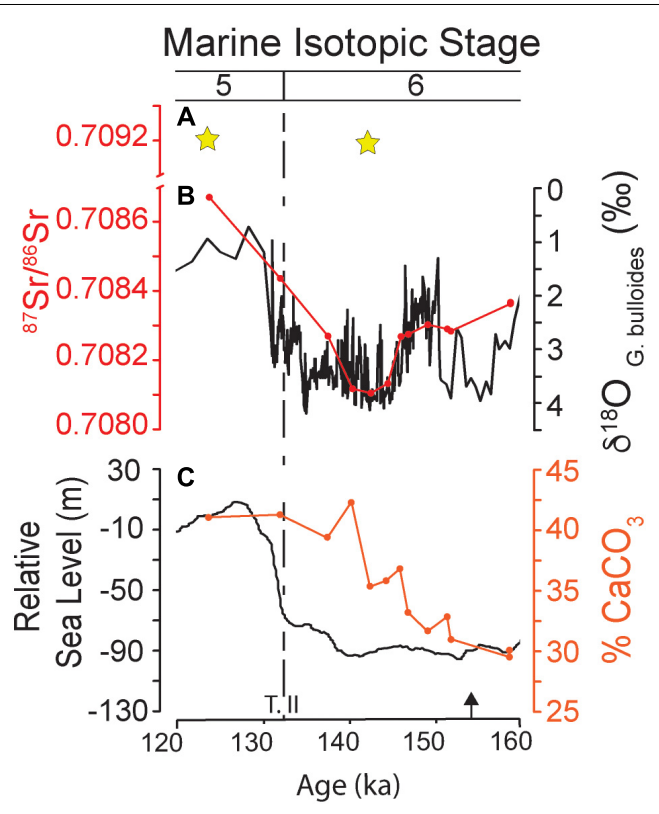

FIGURE 2 | (A) ${ }^{87} \mathrm{Sr} /{ }^{86} \mathrm{Sr}$ measured on pure biogenic foraminifera calcite (yellow stars, this study - PRGL 1-4), (B) $\delta^{18} \mathrm{O}_{\mathrm{G}}$-bulloides (black line, Sierro et al., 2009) and ${ }^{87} \mathrm{Sr} /{ }^{86} \mathrm{Sr}$ measured on bulk carbonate (red line, this study PRGL 1-4), (C) Red Sea sea level record (coreKL09, black curve, Grant et al., 2014) and $\% \mathrm{CaCO}_{3}$ measured on bulk carbonate (orange line, this study PRGL 1-4). The black arrow indicates evidence of extensive melting of the Alpine ice-cap and local glaciers (Toucanne et al., 2009; Bickel et al., 2015).

the present-day seawater Sr isotope composition has to be related to another process. In other words, if the carbonate components preserved in bulk marine samples were purely biogenic then their isotopic composition should be similar to the seawater: 0.709170 $\left( \pm 4.10^{-6}\right.$, Mokedem et al., 2015; Meknassi et al., 2018 and references therein). In order to further confirm the invariance of the sea-water isotopic composition we performed laserablation - MC-ICPMS Sr isotope composition analyses on pure foraminifera and bivalves calcites on the most radiogenic samples (i.e., $120 \mathrm{ka}, \mathrm{S} .90-21 / 22$ ) and the least radiogenic samples (i.e., 142 ka, S.110-59/60). Both samples are statistically indistinguishable from modern sea water composition with isotopic values of $0.70919 \pm 0.0001(2 \sigma)$ and $0.70921 \pm 0.0002(2 \sigma)$ respectively. This clearly demonstrates the continuous connectivity with the global ocean and the fact that short timescale variability recorded in our bulk ${ }^{87} \mathrm{Sr} /{ }^{86} \mathrm{Sr}$ cannot be explained by changes in the isotopic composition of the parent fluid (i.e., seawater). How then can such variability be explained?

In the Gulf of Lion context, the most likely mechanism to explain the observed data is through the export of detrital carbonates from the catchment area. Indeed, carbonates represent about $50 \%$ of the drainage area (relics of the Tethys Ocean, see Figure 1). Recent studies show that long-term denudation of carbonate rocks within the GoL catchment is significant and slope-dependent (Godard et al., 2016; Thomas et al., 2017), enhancing the transfer of carbonates trough rivers' suspended material (i.e., 30 to $60 \%$ of the coarse fraction; Pont et al., 2002). Our river samples contain between 2.0 and 40.3 wt.\% of carbonates (Supplementary Table S1 and Supplementary Figure S1) which strongly support these conclusions. Moreover, the riverine bedloads are characterized by $\mathrm{Sr}$ isotope compositions ranging between 0.70741 and 0.70855 (Supplementary Table S1 and Supplementary Figure S1) which is close to the ${ }^{87} \mathrm{Sr} /{ }^{86} \mathrm{Sr}$ ratios of the different carbonates (i.e., Miocene, Eocene, Cretaceous, Jurassic) present in the catchment area (ranging from 0.70685 to 0.70895; Figure 3 and Supplementary Table S2). Thus, our river ratios likely represent a mixture of the different carbonates end-members (of different age) exposed in the catchment areas (Figure 3). The observed inter-river isotope variability may result from different contributions of mechanical and chemical weathering processes in each watershed and/or reflect the relative proportion of each end-member carbonate unit. In this context, the export of detrital carbonates into marine sediment appears as the best mechanism to explain the observed dataset.

\section{VARIATION THROUGH TIME: COMPOSITION OR PROPORTION?}

A clear distinction in ${ }^{87} \mathrm{Sr} /{ }^{86} \mathrm{Sr}$ of leached carbonate fractions is observed between glacial and interglacial intervals (Figure 2) as deduced from the oxygen isotopic curve obtained in planktonic foraminifera (Globigerina bulloides) and associated age-model from the same core (Sierro et al., 2009; Pasquier et al., 2017). The two samples from interglacial MIS 5 are characterized by ${ }^{87} \mathrm{Sr} /{ }^{86} \mathrm{Sr}$ ratios of 0.70838 and $0.70858(n=2)$ in contrast with less radiogenic composition in glacial sediment (MIS 6) which range from 0.70809 to $0.70832(n=11$, Figure 2$)$. The lowest ${ }^{87} \mathrm{Sr} /{ }^{86} \mathrm{Sr}$ ratios (i.e., $0.70810 \pm 0.00001, n=3$ ) correspond to maximal ice extension and sea-level lowstand.

Contrary to ${ }^{87} \mathrm{Sr} /{ }^{86} \mathrm{Sr}$ ratios, the $\% \mathrm{CaCO}_{3}$ does not track climatic conditions, and is not modulated by depositional conditions across the termination II (T.II $\sim 130 \mathrm{ka}$ ). Instead, $\% \mathrm{CaCO}_{3}$ shows a gradual rise from approx. 30 wt. $\%$ at the onset of MIS 6 (i.e., $160 \mathrm{ka}$ ) to $42 \mathrm{wt} \%$ at the end of the penultimate glacial maxima (i.e., $140 \mathrm{ka}$ ); then it slightly decreases down to 39 wt.\% during the beginning of T.II, before finally rising and reaching a constant value of $\sim 41 \mathrm{wt} . \%$ during the MIS 5 (Figure 2). During glacial times, we observe a greater $\mathrm{CaCO}_{3}$ proportion of what is unexpected considering the low carbonate productivity observed in the western Mediterranean Sea (Hoogakker et al., 2004; Toucanne et al., 2015). Interestingly, this increase in carbonate content is concomitant with a higher detrital flux (Cortina et al., 2013, 2016; Pasquier et al., 2017, 2018); as the rise around $155 \mathrm{ka}$ is synchronous with an extensive melting episode of Alpine ice-caps and local glaciers (Toucanne et al., 2009; Bickel et al., 2015 and reference therein), (Figure 2). This suggests a significant increase of detrital carbonates exported during glacial conditions. This increase might be due to enhanced mechanical glacial and peri-glacial processes such as frost cracking or ablation by glaciers.

The temporal variations in the ${ }^{87} \mathrm{Sr} /{ }^{86} \mathrm{Sr}$ ratios of the carbonate fraction can be explained either by changes in the relative 


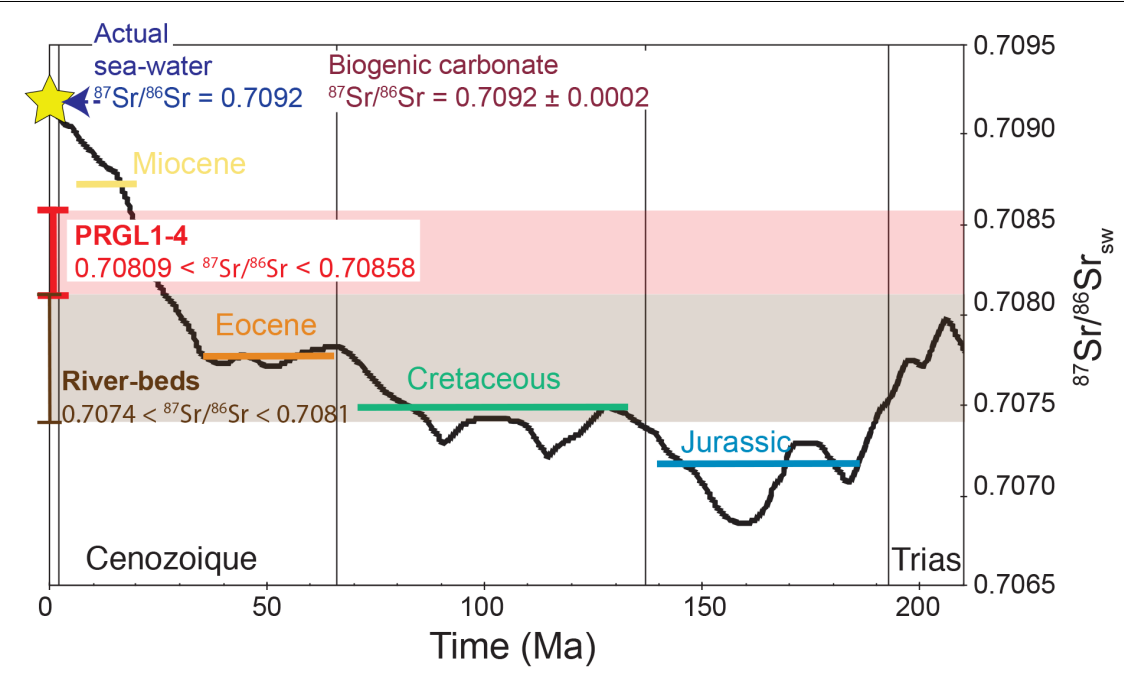

FIGURE $\left.3\right|^{87} \mathrm{Sr} /{ }^{86} \mathrm{Sr}$ evolution of sea-water over the last $210 \mathrm{Ma}$ (black line; Howarth and McArthur, 1997; McArthur et al., 2001), pure biogenic calcite measured on foraminifera shells reflecting the actual sea-water composition. The range of PRGL1-4 leachate deposited over the last 500 kyr is illustrated by the red band and range of rivers sediment in the present-day GoL watershed by a brown band. The main carbonated stratigraphic units and their corresponding Sr isotope compositions in the GoL watershed are also highlighted with horizontal bars corresponding to their mean isotopic composition as defined in Supplementary Table S2.

proportions of biogenic versus detrital carbonates, changes in the isotope composition of detrital carbonates exported into GoL sediment or a combination of both processes.

In the former, the resulting isotope composition of biogenic plus the detrital carbonate mixing processes is typically related to their respective end-member proportion and compositions. Changes in the ${ }^{87} \mathrm{Sr} /{ }^{86} \mathrm{Sr}$ of the carbonate assemblage could be the natural result of an increase or decrease of biogenic carbonate production related to modification of in situ primary production through time. In shelf environments, the biogenic carbonate content is generally controlled by the surface water carbonate productivity, the total amount of carbonate being further controlled by terrigenous sediment dilution effects (Cremer et al., 1992; Hoogakker et al., 2004; Toucanne et al., 2015), with low biogenic $\mathrm{CaCO}_{3}$ production during glacial periods and high biogenic $\mathrm{CaCO}_{3}$ content during interglacial ones. These changes in carbonate production should affect the in situbiogenic versus detrital carbonate proportions, leading to more (less) radiogenic ${ }^{87} \mathrm{Sr} /{ }^{86} \mathrm{Sr}$ during interglacial (glacial) times, as observed in our dataset. However, downcore fluctuations of $\mathrm{CaCO}_{3}$ do not follow the $\delta^{18} \mathrm{O}$ records. Instead, we observed the most important increase in $\% \mathrm{CaCO}_{3}$ during the glacial sensu stricto period (Figure 2). This reveals that, at our site, the $\% \mathrm{CaCO}_{3}$ is not strictly controlled by primary production. Thus, changes in the relative proportion of biogenic carbonates (within the carbonate mixing) cannot on their own explain the observed variation in ${ }^{87} \mathrm{Sr} /{ }^{86} \mathrm{Sr}$.

Interestingly, this increase in $\% \mathrm{CaCO}_{3}$ happened during the period of lower sea level (i.e., glacial maxima), and the less radiogenic values are observed during the lowest sea level conditions (i.e., glacial sensu stricto). At that time, due to sea level fall, PRGL1-4 borehole site is closer to shore $(\sim 10 \mathrm{~km})$ and is therefore more prone to receive and preserve detrital materials.
During interglacial times, the sea-level rise and the biogenic carbonate production increase leading to a relative decrease in the proportion of detrital carbonates preserved in PRGL1-4 sediment. This is also observed at finer timescales during the entire penultimate glaciation where variability of ${ }^{87} \mathrm{Sr} /{ }^{86} \mathrm{Sr}$ closely mimics planktonic oxygen isotopes and sea-level reconstruction (Figure 2 and Supplementary Figure S3). Therefore, ${ }^{87} \mathrm{Sr} /{ }^{86} \mathrm{Sr}$ fluctuations may be related to variation in the relative proportion of exported carbonates. Mixing calculations between biogenic and detrital carbonates are used to test this hypothesis.

$$
\left({ }^{87} \mathrm{Sr} /{ }^{86} \mathrm{Sr}\right)_{\mathrm{m}}=\left[\left({ }^{87} \mathrm{Sr} /{ }^{86} \mathrm{Sr}\right)_{\mathrm{sw}} \cdot \mathrm{X}\right]--\left[\left({ }^{87} \mathrm{Sr} /{ }^{86} \mathrm{Sr}\right)_{\mathrm{d}} \cdot(1-\mathrm{X})\right]
$$

Where $\left({ }^{87} \mathrm{Sr} /{ }^{86} \mathrm{Sr}\right)_{m}$ represent the $\mathrm{Sr}$ isotopic composition measured in PRGL1-4 carbonate fractions; $\left({ }^{87} \mathrm{Sr} /{ }^{86} \mathrm{Sr}\right)_{s w}$ corresponds to seawater composition and $\left({ }^{87} \mathrm{Sr} /{ }^{86} \mathrm{Sr}\right)_{d}$ refers to the isotopic composition of the detrital carbonates. In this equation $\mathrm{X}$ represents the percentage of in situ biogenic carbonates, and (1-X) the required proportion of detrital carbonates in order to satisfy the isotopic mass balance.

Calculation results are shown in Figure 4 where the shaded area illustrates the range of possible ${ }^{87} \mathrm{Sr} /{ }^{86} \mathrm{Sr}$ ratios for the detrital assemblage when considering mixing processes between biogenic carbonates (i.e., ${ }^{87} \mathrm{Sr} /{ }^{86} \mathrm{Sr}=0.70917$ ) and the minimum and maximum ${ }^{87} \mathrm{Sr} /{ }^{86} \mathrm{Sr}$ ratios recorded in the PRGL1-4 sediment carbonate fraction (bottom and top black line, respectively). In this space, the percentage of detrital carbonate can be predicted in order to satisfy the mass balance for a given detrital $\mathrm{Sr}$ isotope composition. We also investigated the impact of detrital assemblage isotope composition on the percentage of detrital carbonate required to fulfill the mixing mass balance equation (Figure 4). This detrital assemblage 


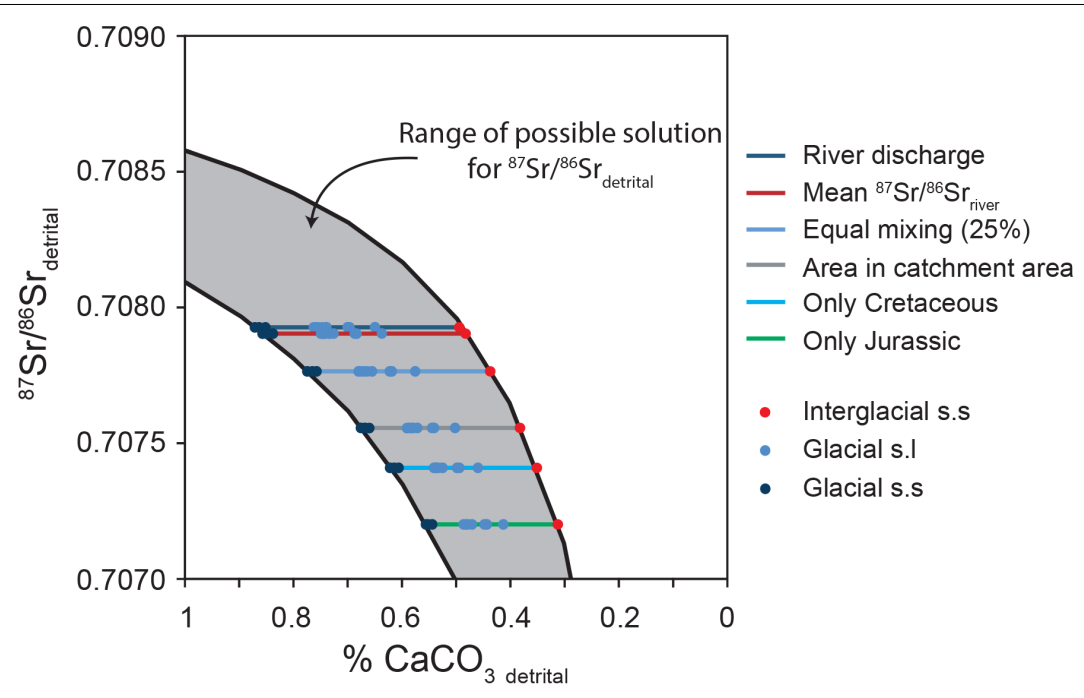

FIGURE 4 | Modeled mixing of a two components system with end-members representing marine biogenic carbonates $\left({ }^{87} \mathrm{Sr} /{ }^{86} \mathrm{Sr}=0.7092\right)$ and an unknown detrital source. The black lines are the predicted ${ }^{87} \mathrm{Sr} /{ }^{86} \mathrm{Sr}$ of the detrital end-member that satisfy the isotopic mass balanced, using the ${ }^{87} \mathrm{Sr} /{ }^{86} \mathrm{Sr}$ of the less (bottom boundary) and more (upper boundary) radiogenic PRGL1-4 samples. The gray shaded area shows the range of possible solutions according to the weight percentage of detrital carbonate in the sediment mixing. Colored horizontal bars represent possible detrital isotopic composition based on mean river discharges (dark blue line), mean ${ }^{87} \mathrm{Sr} /{ }^{86} \mathrm{Sr}$ riverbeds composition (dark red line), exposed surface area in the catchment area (gray line), ${ }^{87} \mathrm{Sr} /{ }^{86} \mathrm{Sr}$ of $\mathrm{Cretaceous} \mathrm{rocks} \mathrm{(cyan}$ line), ${ }^{87} \mathrm{Sr} /{ }^{86} \mathrm{Sr}$ of Jurassic (green line), and equal mixing ratio between carbonated rocks within the catchment area (light blue). Circles represent \% of detrital carbonates in order to obtain the observed ${ }^{87} \mathrm{Sr} /{ }^{86} \mathrm{Sr}$ composition in PRGL1-4 sediment during glacial sensu stricto and sensu lato (i.e., dark and light blue circles, respectively), and interglacial sensu stricto (i.e., red circles).

isotope composition was calculated by averaging the mean river ${ }^{87} \mathrm{Sr} /{ }^{86} \mathrm{Sr}$ ratios (red line on Figure 4), using either a single carbonate value [as highlighted in Figure 3 (i.e., using the average of the LOWESS numerical fitted curve of McArthur et al. (2012) giving Cretaceous ${ }^{87} \mathrm{Sr} /{ }^{86} \mathrm{Sr}=0.707406$, Jurassic ${ }^{87} \mathrm{Sr} /{ }^{86} \mathrm{Sr}=0.707199$, respectively cyan and green line on Figure 4)], or resulting from mixing in rivers. In the latter, we used several multi- component mixing, using individual river ${ }^{87} \mathrm{Sr} /{ }^{86} \mathrm{Sr}$ composition and assuming different relative proportions as a function of: (1) river discharges (i.e., ${ }^{87} \mathrm{Sr} /{ }^{86} \mathrm{Sr}=0.70793$; dark blue), (2) percentage of the exposed carbonated surface in the catchment area (i.e., ${ }^{87} \mathrm{Sr} /{ }^{86} \mathrm{Sr}=0.70756$; gray line), and (3) assuming an equal mixing between all carbonated rocks in the catchment (i.e., $25 \%$ of each carbonate unit exposed; ${ }^{87} \mathrm{Sr} /{ }^{86} \mathrm{Sr}=0.7077$; light blue), see Figure 4 and Supplementary Table S2. Our results show variation of the relative contribution of detrital carbonates (i.e., $\% \mathrm{CaCO}_{3}$ detrital) over glacial-interglacial cycles (Figure 4). Using the different scenarios presented above, we also suggest that a higher proportion of detrital carbonates are preserved during glacial sensu stricto (55 and $87 \%$ ) compared to interglacial (31 to $49 \%$ ) samples, respectively dark blue and red points in Figure 4. We also note that this observation is independent of the isotopic composition of the detrital exported material because whatever the Sr isotope composition of the detrital carbonate fraction is, the required amount of detrital carbonate is always higher during glacial periods. Therefore, ${ }^{87} \mathrm{Sr} /{ }^{86} \mathrm{Sr}$ fluctuation may result from sea-level variability, with sea-level lowstand allowing a better deposition/preservation of detrital carbonates on the GoL's upper slope.
Alternatively, if we assume that detrital carbonates are exported at a constant rate, variation in their strontium isotopic composition could also explain our data. As we showed previously, the GoL catchment area is mainly composed of Mesozoic and Cenozoic marine limestone that are characterized by a large range of ${ }^{87} \mathrm{Sr} /{ }^{86} \mathrm{Sr}$ ratios, and where Miocene carbonate ${ }^{87} \mathrm{Sr} /{ }^{86} \mathrm{Sr}>$ Eocene carbonate ${ }^{87} \mathrm{Sr} /{ }^{86} \mathrm{Sr}>$ Cretaceous carbonate ${ }^{87} \mathrm{Sr} /{ }^{86} \mathrm{Sr}>$ Jurassic carbonate ${ }^{87} \mathrm{Sr} /{ }^{86} \mathrm{Sr}$ (Figure 3). Changes in the $\mathrm{Sr}$ isotope composition of the PRGL1-4 carbonate fraction can result from variations in the Sr isotope composition of the detrital end-member. Thus, our data could indicate sedimentary mixing of biogenic carbonate with less radiogenic detrital carbonates during glacial times, possibly enhanced by greater inputs of Jurassic or Cretaceous units. Indeed, at the time of minimum ${ }^{87} \mathrm{Sr} /{ }^{86} \mathrm{Sr}$ ratio (glacial) our mixing model predicts less radiogenic detrital carbonates, as indicated by the lower boundary of the shaded area (Figure 4). By contrast, more radiogenic detrital carbonates are required during interglacial stages, as indicated by the upper boundary (Figure 4). For instance, if we consider that $90 \%$ of the carbonates result from detrital export, then the isotopic composition of the detrital source should have evolved from 0.7080 during the glacial sensu stricto to 0.7850 during the interglacial sensu stricto. Such variability in the detrital ${ }^{87} \mathrm{Sr} /{ }^{86} \mathrm{Sr}$ ratio should be interpreted as the natural response to various mechanical and chemical weathering processes and/or spatial changes in sediment provenance in the catchment.

The directionality of the relation between sea-level change and ${ }^{87} \mathrm{Sr} /{ }^{86} \mathrm{Sr}_{\text {carb }}$ observed here, and the timing between the increase in $\% \mathrm{CaCO}_{3}$ and the Alpine ice cap collapse around 150 
$\mathrm{ka}$, argue for the export and preservation of detrital carbonates from the catchment to the GoL shelf. This provides a powerful way to reconstruct past detrital carbonate exports in Source-toSink systems.

\section{IMPLICATION FOR FLUXES RECONSTRUCTIONS}

Stratigraphic knowledge of the area relies on previous studies based on seismic and PROMESS drilling data in the Gulf of Lion (Rabineau, 2001; Rabineau et al., 2005, 2006; Bassetti et al., 2008; Leroux et al., 2016 among others; see detailed methodology in the Section "Materials and Methods").

We focused our sediment budget within the so-called Sequence 3, in which enough high-resolution seismic data allowed identification of two sedimentary units, U75 and U80, that, respectively correspond to an interglacial and glacial period (respectively Marine Isotopic Stages 9 and 8), (Supplementary Figure S4).

Previously reported sediment budgets obtained for these units were first corrected from porosity to calculate "deposited" terrigenous solid volumes. Considering that $\% \mathrm{CaCO}_{3}$ reflects in situ biogenic primary production, "deposited" sediment volumes are corrected to get the "detrital" sediment budget.

In order to investigate the impact of the detrital/biogenic ratio on sediment flux calculation, we then applied the detrital carbonate estimations established for MIS 5 (i.e., 30-50\%) and 6 (i.e., 55-85\%), assuming it is suitable for MIS 8 and MIS 9, in order to calculate "true" detrital sediment budgets (Supplementary Figure S5 and Supplementary Table S3). Considering the only uncertainties about detrital carbonate content, we observe that "true" detrital sediment estimates within a single unit yield a systematic increase whatever the climatic conditions. Additional detrital sediment represents an addition of 78 to $130 \mathrm{~km}^{3}$.Myr and 128 to $199 \mathrm{~km}^{3}$.Myr, respectively for MIS 9 and MIS 8, corresponding to +20 to $+33 \%$ and +23 to $+36 \%$ detrital fluxes, respectively. Our conclusions imply an overall under-estimate of (detrital) sediment supply in Sourceto-Sink studies when carbonate content is not examined. This observation is valid for both glacial and interglacial periods, with variable magnitude but is high enough to be considered. Consequently, corrections from in situ carbonate production appears critical for future quantitative studies in Source-to-Sink routing systems.

As the terrigenous sediment budget of passive margin basins records variations in the continental relief, triggered by either deformation or climate, it becomes a major challenge to determine sediment accumulation histories in a large number of basins found in various geodynamic contexts (Guillocheau et al., 2012). Usually, Source-to-Sink studies try to relate significant changes in sediment flux to significant changes in terms of climate or deformation, through the geological history of the studied area. But the concept of "significance" is largely dependent on the uncertainties and the time-resolution of the study. And, as previous authors underlined, "the assessment of the associated uncertainties are as important as the accumulation values themselves." Indeed, if uncertainties are underestimated, some "apparent" changes in sediment fluxes may not be significant in terms of climate or tectonic changes and may lead to misinterpretations.

However, assessing these uncertainties still remains tricky. To do so, we need to consider and quantify to what extent each factor (i.e., autogenic and allogenic) impacts sediment budget measurement, in addition to the uncertainties strictly related to the method itself (e.g., such as the seismic resolution and borehole age uncertainties). Further work is therefore needed to refine our method, particularly in order to better define the characteristics of the detrital end-member and to therefore more accurately estimate its magnitude.

Moreover, Source-to-Sink sedimentary systems are important settings of carbon cycling, serving as sites of carbon transfer between terrestrial and marine reservoirs, and as the primary locations for organic carbon burial on Earth (Leithold et al., 2016). Whereas the order of magnitude for in situ carbonate correction that is measured in this study appears lower than many other uncertainties in some cases, it should be nevertheless interesting to analyze Sr isotopes in Source-to-Sink studies where in situ carbonate production (autogenic factor) can "introduce noise, lags and/or completely mask signals of external forcings" (Romans et al., 2016). It may be particularly true for basins with low sediment accumulation rates where small variations of detrital sediment fluxes, including detrital carbonate, can be significant in term of climate or tectonic change. As well as in Source-to-Sink systems (i) exhibiting small sediment supplies, (ii) including few carbonated rocks in the catchment area (i.e., detrital carbonate flux toward the sink), or (iii) bad preservation of detrital sediment (sediment by-pass). Conversely, $\mathrm{Sr}$ isotope analyses may also be relevant for areas where biogenic production (and carbonate preservation) is particularly high or where productivity (and associated export in the surrounding basin) is very unstable throughout time, such as a carbonated/mixed platform.

We can now wonder (i) how far this under-estimate can change from one basin to another, and (ii) how far this error could have led to potential previous misinterpretations in term of "true" changes on sediment history and processes at their origin, especially for studies exploring glacial and interglacial cycles.

Overall, as already postulated by Helland-Hansen et al. (2016), this study highlights the usefulness of developing isotopic tools and using combined approaches to better refine our understanding of Source-to-Sink systems and to unravel past source terrains.

\section{IMPLICATIONS FOR DEEP-TIME SR ISOTOPE CHEMOSTRATIGRAPHY}

Temporal variations in the marine ${ }^{87} \mathrm{Sr} /{ }^{86} \mathrm{Sr}$ record globally reflect variations in the relative age-weighted fluxes of continental weathering relative to hydrothermal inputs over time, although other sources such as oceanic islands have to be considered (Revillon et al., 2007). Such variations are linked to supercontinent breakup and assembly and sea-level changes 
(e.g., Burke et al., 1982; De Paolo and Ingram, 1984; Haq et al., 1988; Veizer, 1989; Veizer et al., 1999; Prokoph et al., 2008) and are used extensively in the Precambrian era. Moreover, in the absence of robust biostratigraphic records and absolute chronological constraints, ${ }^{87} \mathrm{Sr} /{ }^{86} \mathrm{Sr}$ records are a critical tool for inter- and intra-basinal correlations in the Precambrian era. However, the absence of calcifying organisms means that all Precambrian (and many early Paleozoic) ${ }^{87} \mathrm{Sr} /{ }^{86} \mathrm{Sr}$ values come from microdrilled bulk carbonate samples (e.g., Halverson et al., 2007).

Most of the available geologic records of marine sedimentary rocks predominantly preserve sediment deposited on the continental paleo-shelf (Peters and Husson, 2017), where carbonate facies are abundant (Grotzinger, 1990; Grotzinger and Knoll, 1999; Higgins et al., 2009). Consequently, bulk samples can include detrital carbonates.

Still, if detrital carbonates had the ability to reach marine sediment since the emergence of the continent, we can wonder how much carbonated outcrops were likely to be weathered (and preserved over paleo-shelf). Currently, there is no reconstruction of such flux, but a simple geochemical argument can be made: $\mathrm{CO}_{2}$ has been emitted into the ocean-atmosphere as long as volcanic activity existed, i.e., since the very beginning (Tailor and McLennan, 1985; Jacobsen, 1988; Ying et al., 2011). As $\mathrm{CO}_{2}$ cannot indefinitely accumulate in the atmosphere, it sank as carbonate mineral and organic matter, at least since the last 3.8 billion years (Schidlowski, 2001). Carbon isotope compilation over the geological record (e.g., Schidlowski, 2001) suggests that approximatively $80 \%$ of the $\mathrm{CO}_{2}$ source has been removed as carbonates over that entire time. This is a firstorder approximation, and there is many details and caveats, but it reveals that carbonates have been formed over much of Earth's history. Today most carbonates form biologically, while in the Precambrian and early Proterozoic era they formed abiotically (Higgins et al., 2009). In addition, and in contrast with the Phanerozoic era, past ocean chemistry (i.e., high silica content) promoted silicification of most Precambrian and early Proterozoic depositional environments (Siever, 1992; Treguer et al., 1995; Hofmann and Wilson, 2007 among others). Meaning that deep-time carbonates were probably more competent upon uplift and exposure, and therefore were even more likely to be transported to the ocean and "contaminate" the bulk Sr samples.

The above considerations suggest that variations in the resulting ${ }^{87} \mathrm{Sr} /{ }^{86} \mathrm{Sr}$ values within and between basins could potentially also reflect differential detrital carbonate components, impacting both stratigraphic correlations as well as our understanding of tectonic evolution over time. Therefore, it seems critical to consider the potential impact that detrital carbonate may have on these records.

\section{REFERENCES}

Allègre, C. J., Louvat, P., Gaillardet, J., Meynadier, L., Rad, S., and Capmas, F. (2010). The fundamental role of island arc weathering in the oceanic Sr isotope budget. Earth Planet. Sci. Lett. 292, 51-56. doi: 10.1016/j.epsl.2010.01.019

\section{DATA AVAILABILITY}

Publicly available datasets were analyzed in this study. This data can be found here: https://www.pangaea.de/?q=PROMESS1.

\section{AUTHOR CONTRIBUTIONS}

VP, SR, and MR conceived the work. VP, SR, LM, and SM organized the sampling. VP and SR carried out the geochemical analyses. VP, SR, EL, SM, and MR wrote the manuscript and the Supplementary Information. All authors discussed the interpretation of the results and contributed to the manuscript.

\section{FUNDING}

This work was supported by the "Laboratoires d'Excellence" LabexMER (ANR-10-LABX-19) that became ISblue (Interdisciplinary graduate School for the Blue Planet ANR17-EURE-0015); and co-funded by a grant from the French government under the program "Investissements d'Avenir," and by a grant from the Regional Council of Brittany. It was further supported by the CNRS (INSU-Tellus-SYSTER for the Carboflux project), with additional support from the French Actions Marges program. The drilling operation was conducted within the European Commission Project PROMESS (contract EVR1-CT-2002-40024).

\section{ACKNOWLEDGMENTS}

The European Promess Scientific committee and colleagues at Ifremer are thanked for previous contributions of data acquisition, processing, interpretations, and permitting to resample the borehole. The authors warmly acknowledge C. Liorzou and P. Nonnotte who kindly helped during the analytical preparation of samples, and for assistance on the ICP-OES and TI-MS, respectively. D. Fike is thanked for fruitful discussion and his feedback along the entire study; Itay Halevy and Peter Crockford for providing comments and suggestions regarding the importance of such processes on deep time reconstructions.

\section{SUPPLEMENTARY MATERIAL}

The Supplementary Material for this article can be found online at: https://www.frontiersin.org/articles/10.3389/feart. 2019.00164/full\#supplementary-material

Allen, J. R. (1974). Reaction, relaxation and lag in natural sedimentary systems: general principles, examples and lessons. Earth Sci. Rev. 10, 263-342. doi: 10.1016/0012-8252(74)90109-3

Allen, P. A. (2008). From landscapes into geological history. Nature 451, 274-276. doi: $10.1038 /$ nature 06586 
Aloisi, C. J., Auffret, G. A., Auffret, J. P., Barusseau, J. P., Hommeril, P., Larsonneur, C., et al. (1977).. Essai de modélisation de la sédimentation actuelle sur les plateaux continentaux français. Bull. Soc. Géol. France 7, 183-195 doi: 10.2113/ gssgfbull.s7-xix.2.183

Armitage, J. J., Duller, R. A., Whittaker, A. C., and Allen, P. A. (2011). Transformation of tectonic and climatic signals from source to sedimentary archive. Nat. Geosci. 4, 231-235. doi: 10.1038/ngeo1087

Armitage, J. J., Jones, T. D., Duller, R. A., Whittaker, A. C., and Allen, P. A. (2013). Temporal buffering of climate-driven sediment flux cycles by transient catchment response. Earth Planet. Sci. Lett. 36, 200-210. doi: 10.1016/j.epsl. 2013.03.020

Bassetti, M. A., Berné, S., Jouet, G., Taviani, M., Dennielou, B., Flores, J. A., et al. (2008). The 100-ka and rapid sea level changes recorded by prograding shelf sand bodies in the gulf of lions (western Mediterranean Sea). Geochem. Geophys. Geosyst. 9:Q11R05. doi: 10.1029/2007GC001854

Bickel, L., Lüthgensa, C., Lomaxb, J., and Fiebig, M. (2015). The timing of the penultimate glaciation in the northern alpine foreland: new insights from luminescence dating. Proc. Geol. Assoc. 126, 536-550. doi: 10.1016/j.pgeola. 2015.08.002

Broeker, W. (1963). "Radioisotopes and large-scale oceanic mixing," in The Composition of Seawater: Comparative and Descriptive Oceanography. the Sea: Ideas and Observations on Progress in the Study of the Seas, ed. M. N. Hill (New York, NY: Wiley Interscience).

Burke, W. H., Denison, R. E., Hetherington, E. A., Koepnick, R. B., Nelson, H. F., and Otto, J. B. (1982). Variation of seawater $87 \mathrm{Sr} / 86 \mathrm{Sr}$ throughout phanerozoic time. Geology 10, 516-519.

Castelltort, S., and Van Den Driessche, J. (2003). How plausible are high-frequency sediment supply-driven cycles in the stratigraphic record? Sediment. Geol. 157, 3-13. doi: 10.1016/S0037-0738(03)00066-6

Cortina, A., Grimalt, J. O., Rigual-Hernández, A., Ballegeer, A.-M., Martrat, B., Sierro, F. J., et al. (2016). The impact of ice-sheet dynamics in western mediterranean environmental conditions during terminations: an approach based on terrestrial long chain n-alkanes deposited in the upper slope of the gulf of lions. Chem. Geol. 430, 21-33. doi: 10.1016/j.chemgeo.2016.03.015

Cortina, A., Sierro, F. J., Filippelli, G., Flores, J.-A., and Berné, S. (2013). Changes in planktic and benthic foraminifer assemblages in the gulf of lions, off south france: response to climate and sea level change from MIS 6 to MIS 11. Geochem. Geophys. Geosyst. 14, 1258-1276. doi: 10.1002/ggge.20096

Cremer, M., Grousset, F., Faugères, J. C., Duprat, J., and Gonthier, E. (1992). Sediment flux patterns in the northeastern atlantic: variability since the last interglacial. Mar. Geol. 104, 31-53. doi: 10.1016/0025-3227(92)90083-T

De Paolo, D. J., and Ingram, B. L. (1984). High-resolution stratigraphy with strontium isotopes. Science 227, 938-940.

de Madron, X. D., Abassi, A., Heussner, S., Monaco, A., Aloisi, J. C., Radakovitch, O., et al. (2000). Particulate matter and organic carbon budgets for the Gulf of Lions (NW Mediterranean). Oceanologica Acta 23, 717-730. doi: 10.1016/ S0399-1784(00)00119-5

Elderfield, H. (1986). Strontium isotope stratigraphy. Palaeogeogr. Palaeoclimatol. Palaeoecol. 57, 71-90. doi: 10.1016/0031-0182(86)90007-6

Frigola, J., Canals, M., Cacho, I., Moreno, A., Sierro, F. J., Flores, J. A., et al. (2012). A $500 \mathrm{kyr}$ record of global sea-level oscillations in the Gulf of Lion, mediterranean Sea: new insights into MIS 3 sea-level variability. Clim. Past 8, 1067-1077. doi: 10.5194/cp-8-1067-2012

Godard, V., Ollivier, V., Bellier, O., Miramont, C., Shabanian, E., Fleury, J., et al. (2016). Weathering-limited hillslope evolution in carbonate landscapes. Earth Planet. Sci. Lett. 446, 10-20. doi: 10.1016/j.epsl.2016.04.017

Goldberg, E. D. (1963). “The ocean as a chemical system", in The Sea, ed. M. N. Hill (New York, NY: Intersciences).

Grant, K. M., Rohling, E. J., Ramsey, C. B., Cheng, H., Edwards, R. L., Florindo, F., et al. (2014). Sea-level variability over five glacial cycles. Nat. Commun. 5:5076. doi: $10.1038 /$ ncomms 6076

Grotzinger, J. P. (1990). Geochemical model for proterozoic stromatolite decline. Am. J. Sci. 290A, 80-103.

Grotzinger, J. P., and Knoll, A. H. (1999). Stromatolites in precambrian carbonates: evolutionary mileposts or environmental dipsticks. Annu. Rev. Earth Planet. Sci. 27, 313-358. doi: 10.1146/annurev.earth.27.1.313

Guillocheau, F., Rouby, D., Robin, C., Helm, C., and Rolland, N. (2012). Quantification and causes of the terrigeneous sediment budget at the scale of a continental margin: a new method applied to the Namibia-South Africa margin. Basin Res. 24, 3-30. doi: 10.1111/j.1365-2117.2011.00511.x

Halverson, G. P., Dudás, F. Ö, Maloof, A. C., and Bowring, S. A. (2007). Evolution of the $87 \mathrm{Sr} / 86 \mathrm{Sr}$ composition of Neoproterozoic seawater. Palaeoclimatol. Palaeoecol. Palaeogeogr. 256, 103-129. doi: 10.1016/j.palaeo.2007.02.028

Haq, B. U., Hardenbol, J., and Vail, P. R. (1988). "Mesozoic, and cenozoic chronostratigraphy, and eustatic cycles. sea-level changes," in Sea Level Changes: An Integrated Approach, ed. C. K. Wilgus, et al. (Houston: SEPM Special Publication).

Helland-Hansen, W., Sømme, T. O., Martinsen, O. J., Lunt, I., and Thurmond, J. (2016). Deciphering earth's natural hourglasses: perspectives on source-to-sink analysis. J. Sediment. Res. 86, 1008-1033. doi: 10.2110/jsr.2016.56

Hernández-Molina, F. J., Stow, D. A. V., Alvarez-Zarikian, C. A., Acton, G., Bahr, A., Balestra, B., et al. (2014). Onset of mediterranean outflow into the North Atlantic. Science 344, 1244-1250. doi: 10.1126/science.1251306

Higgins, J. A., Fischer, W. W., and Schrag, D. P. (2009). Oxygenation of the ocean and sediments: consequences for the seafloor carbonate factory. Earth Planet. Sci. Lett. 284, 25-33. doi: 10.1016/j.epsl.2009.03.039

Hodell, D. A., Mead, G. A., and Mueller, P. A. (1990). Variation in the strontium isotopic composition of seawater ( $8 \mathrm{Ma}$ to present) Implications for chemical weathering rates and dissolved fluxes to the oceans. Isot. Geosci. 80, 291-307. doi: 10.1016/0168-9622(90)90011-Z

Hofmann, A., and Wilson, A. H. (2007). "Silicified basalts, bedded cherts and other sea floor alteration phenomena of the 3.4 Ga Nondweni greenstone belt," in Earth's Oldest Rocks, eds J. Martin, R. Van Kranendonk, H. Smithies, C. Vickie, and J. Bennett. (Amsterdam: Elsevier)

Hoogakker, B. A. A., Rothwell, R. G., Rohling, E. J., Paterne, M., Stow, D. A. V., Herrle, J. O., et al. (2004). Variations in terrigenous dilution in western mediterranean sea pelagic sediments in response to climate change during the last glacial cycle. Mar. Geol. 211, 21-43. doi: 10.1016/j.margeo.2004.07.005

Howarth, R. J., and McArthur, J. M. (1997). Statistics for strontium isotope stratigraphy: a robust LOWESS fit to the marine Sr-isotope curve for 0 to 206 $\mathrm{Ma}$, with look-up table for derivation of numeric age. J. Geol. 105, 441-456. doi: $10.1086 / 515938$

Jacobsen, S. B. (1988). Isotopic constraints on crustal growth and recycling. Earth Planet. Sci. 90, 315-329. doi: 10.1016/0012-821X(88)90133-90131

Leithold, E. L., Blair, N. E., and Wegmann, K. W. (2016). Source-to-sink sedimentary systems and global carbon burial: a river runs through it. Earth Sci. Rev. 153, 30-42. doi: 10.1016/j.earscirev.2015.10.011

Leroux, E., Rabineau, M., Aslanian, D., Gorini, C., Molliex, S., Bache, F., et al. (2016). High-resolution evolution of terrigenous sediment yields in the provence basin during the last $6 \mathrm{Ma}$ : relation with climate and tectonics. Basin Res. 29, 305-339. doi: 10.1111/bre.12178

McArthur, J. M. (1994). Recent trends in strontium isotope stratigraphy. Terra Nova 6, 331-358. doi: 10.1111/j.1365-3121.1994.tb00507.x

McArthur, J. M., Howarth, R. J., and Bailey, T. R. (2001). Strontium isotope stratigraphy: LOWESS Version 3: best Fit to the marine Sr-Isotope Curve for 0-509 Ma and accompanying look-up table for deriving numerical age. J. Geol. 109, 155-170. doi: 10.1086/319243

McArthur, J. M., Howarth, R. J., and Shields, G. A. (2012). "Strontium isotope stratigraphy," in Gradstein, eds J. G. Ogg, M. D. Schmitz, and G. M. Ogg (Amsterdam: Elsevier).

Meknassi, E. S., Dera, G., Cardone, T., De Rafélis, M., Brahmi, C., and Chavagnac, V. Sr. (2018). isotope ratios of modern carbonate shells: good and bad news for chemostratigraphy. Geology 46, 1003-1006. doi: 10.1130/G45380.1

Mokedem, F., Parkinson, I. J., Hathorne, E., Anand, P., Allen, J., Burton, K., et al. (2015). High-precision radiogenic strontium isotope measurements of the modern and glacial ocean: limits on glacial-interglacial variations in continental weathering. Earth Planet. Sci. Lett. 415, 111-120. doi: 10.1016/j.epsl.2015. 01.036

Molliex, S., Rabineau, M., Leroux, E., Bourlès, D. L., Authemayou, C., Aslanian, D., et al. (2016). Multi-approach quantification of denudation rates in the Gulf of Lion source-to-sink system (SE France). Earth Planet. Sci. Lett. 444, 101-115. doi: 10.1016/j.epsl.2016.03.043

Pasquier, V., Sansjofre, P., Lebeau, O., Liorzou, C., and Rabineau, M. (2018). Acid digestion on river influenced shelf sediment organic matter: carbon and nitrogen contents and isotopic ratios. Rapid Commun. Mass Spectrom. 32, 86-92. doi: $10.1002 / \mathrm{rcm} .8014$ 
Pasquier, V., Sansjofre, P., Rabineau, M., Revillon, S., Houghton, J., and Fike, D. A. (2017). Pyrite sulfur isotopes reveal glacial-interglacial environmental changes. Proc. Natl. Acad. Sci. U.S.A. 114, 5941-5945. doi: 10.1073/pnas.1618245114

Peters, S. E., and Husson, J. M. (2017). Sediment cycling on continental and oceanic crust. Geology 45, 323-326. doi: 10.1130/G38861.1

Pont, D., Simonnet, J. P., and Walter, A. V. (2002). Medium-term changes in suspended sediment delivery to the ocean: consequences of catchment heterogeneity and river management (Rhône River, France). Estuar. Coast. Shelf Sci. 54, 1-18. doi: 10.1006/ecss.2001.0829

Prokoph, A., Shields, G. A., and Veizer, J. (2008). Compilation and time-series analysis of a marine carbonate $\delta 18 \mathrm{O}, \delta 13 \mathrm{C}, 87 \mathrm{Sr} / 86 \mathrm{Sr}$ and $\delta 34 \mathrm{~S}$ database through earth history. Earth Sci. Rev. 87, 113-133. doi: 10.1016/j.earscirev.2007. 12.003

Rabineau, M. (2001). Un modèle géométrique et stratigraphique des séquences de dépôts quaternaires de la plate-forme du Golfe du Lion: enregistrement des cycles glacioeustatiques de 100000 ans. Ph.D thesis, Université de Rennes1, $\iota$ Rennes.

Rabineau, M., Berné, S., Aslanian, D., Olivet, J.-L., Joseph, P., Guillocheau, F., et al. (2005). Sedimentary sequences in the Gulf of Lion: a record of 100,000 years climatic cycles. Mar. Petrol. Geol. 22, 775-804. doi: 10.1016/j.marpetgeo.2005. 03.010

Rabineau, M., Berné, S., Olivet, J.-L., Aslanian, D., Guillocheau, F., and Joseph, P. (2006). Paleo sea levels reconsidered from direct observation of paleoshoreline position during glacial maxima (for the las 500,000 yr). Earth Planet. Sci. Lett. 252, 119-137. doi: 10.1016/j.epsl.2006.09.033

Rabineau, M., Leroux, E., Aslanian, D., Bache, F., Gorini, C., Moulin, M., et al. (2014). Quantifying subsidence and isostatic readjustment using sedimentary paleomarkers, example from the Gulf of Lion. Earth Planet. Sci. Lett. 388, 353-366. doi: 10.1016/j.epsl.2013.11.059

Railsback, L. B., Gibbard, P. L., Head, M. J., Voarintsoa, N. R. G., and Toucanne, S. (2015). An optimized scheme of lettered marine isotope substages for the last 1.0 million years, and the climatostratigraphic nature of isotope stages and substages. Quat. Sci. Rev. 111, 94-106. doi: 10.1016/j.quascirev.2015.01.012

Revillon, S., Jouet, G., Bayon, G., Rabineau, M., Dennielou, B., Hémond, C., et al. (2011). The provenance of sediments in the Gulf of Lions, western mediterranean Sea. Geochem. Geophys. Geosyst. 12, 1-20. doi: 10.1029/ 2011GC003523

Revillon, S., Teagle, D. A. H., Boulvais, P., Shafer, J., and Neal, C. R. (2007). Geochemical fluxes related to alteration of a subaerially-exposed seamount: nintoku seamount, ODP Leg 197, Site 1205. Geochem. Geophys. Geosyst. 8, $1-26$.

Rohling, E. J., Foster, G. L., Grant, K. M., Marino, G., Roberts, A. P., Tamisiea, M. E., et al. (2014). Sea-level and deep-sea-temperature variability over the past 5.3 million years. Nature 508, 477-482. doi: 10.1038/nature 13230

Romans, B. W., Castelltort, S., Covault, J. A., Fildani, A., and Walsh, J. P. (2016). Environmental signal propagation in sedimentary systems across timescales. Earth Sci. Rev. 153, 7-29. doi: 10.1016/j.earscirev.2015. 07.012

Schidlowski, M. (2001). Carbon isotopes as biogeochemical recorders of life over $3.8 \mathrm{Ga}$ of earth history: evolution of a concept. Precambrian Res. 106, 117-134. doi: $10.1016 / 50301-9268(00) 00128-125$
Sierro, F. J., Andersen, N., Bassetti, M. A., Berné, S., Canals, M., Curtis, J. H., et al. (2009). Phase relationship between sea level and abrupt climate change. Quat. Sci. Rev. 28, 2867-2881. doi: 10.1016/j.quascirev.2009.07.019

Siever, R. (1992). The silica cycle in precambrian. Geochim. Cosmochim. Acta 56, 3365-3272.

Simpson, G., and Castelltort, S. (2012). Model shows that rivers transmit highfrequency climate cycles to the sedimentary record. Geology 40, 1131-1134. doi: $10.1130 / G 33451.1$

Tailor, S. R., and McLennan, S. M. (1985). The Continental Crust: its Composition and Evolution. Hoboken, NY: Blackwell Scientific Publications.

Thomas, F., Godard, V., Bellier, O., Shabanian, E., Ollivier, V., Benedetti, L., et al. (2017). Morphological controls on the dynamics of carbonate landscapes under a mediterranean climate. Terra Nova 29, 173-182. doi: 10.1111/ter. 12260

Toucanne, S., Minto'o, C. M. A., Fontanier, C., Bassetti, M.-A., Jorry, S. J., and Jouet, G. (2015). Tracking rainfall in the northern Mediterranean borderlands during sapropel deposition. Quat. Sci. Rev. 129, 178-195. doi: 10.1016/j. quascirev.2015.10.016

Toucanne, S., Zaragosi, S., Bourillet, J. F., Cremer, M., Eynaud, F., Van VlietLanoë, B., et al. (2009). Timing of massive Fleuve Manche discharges over the last 350kyr: insights into the european ice-sheet oscillations and the european drainage network from MIS 10 to 2. Quat. Sci. Rev. 28, 1238-1256. doi: 10.1016/ j.quascirev.2009.01.006

Treguer, P., Nelson, D. M., and Van Bennekom, A. J. (1995). The silica balance in the world ocean: a reestimate. Science 268, 375-379. doi: 10.1126/science.268. 5209.375

Veizer, J. (1989). Strontium isotopes in seawater through time. Annu. Rev. Earth Planet. Sci. 17, 141-167. doi: 10.1146/annurev.earth.17.1.141

Veizer, J., Buhl, D., Diener, A., Ebneth, S., Podlaha, O. G., Bruckschen, P., et al. (1997). Strontium isotope stratigraphy: potential resolution and event correlation. Palaeogeogr. Palaeoclimatol. Palaeoecol. 132, 65-77. doi: 10.1016/ S0031-0182(97)00054-0

Veizer, J. N., Ala, D., Azmy, K., Bruckschen, P., Buhl, D., Bruhn, F., et al. (1999). $87 \mathrm{Sr} / 86 \mathrm{Sr}$, d13C and d18O evolution of phanerozoic seawater. Chem. Geol. 161, 59-88. doi: 10.1016/S0009-2541(99)00081-9

Ying, J.-F., Zhou, X.-H., Su, B.-X., and Tang, Y.-J. (2011). Continental growth and secular evolution: constraints from $\mathrm{U}-\mathrm{Pb}$ ages and $\mathrm{Hf}$ isotope of detrital zircons in Proterozoic jixian sedimentary section (1.8-0.8Ga), North China craton. Precambrian Res. 189, 229-238. doi: 10.1016/j.precamres.2011.07.007

Conflict of Interest Statement: The authors declare that the research was conducted in the absence of any commercial or financial relationships that could be construed as a potential conflict of interest.

Copyright (c) 2019 Pasquier, Revillon, Leroux, Molliex, Mocochain and Rabineau. This is an open-access article distributed under the terms of the Creative Commons Attribution License (CC BY). The use, distribution or reproduction in other forums is permitted, provided the original author(s) and the copyright owner(s) are credited and that the original publication in this journal is cited, in accordance with accepted academic practice. No use, distribution or reproduction is permitted which does not comply with these terms. 